\title{
ANALISIS PERMINTAAN BERAS ORGANIK DI KOTA SURAKARTA
}

\author{
Dina Fitriah $^{* 1}$, Sri Marwanti ${ }^{1}$, Ernoiz Antriyandati ${ }^{1}$ \\ ${ }^{1}$ Program Studi Agribisnis Fakultas Pertanian; Universitas Sebelas Maret \\ e-mail: ${ }^{* 1}$ ernoiz_a@staff.uns.ac.id
}

\begin{abstract}
Research aims to understand variable influence the price of organic rice, the price of nonorganic rice, chicken egg price, education, income, the number of family members, preference on the organic rice in the city of surakarta and elasticity demand. The basic method used in this research is descriptive and analytical method with survey research technique. The method of determining the location of the research is aimed at Surakarta City. The sampling method used is accidental sampling with 100 respondents. Data analysis used the multiple linear regression analysis. This research result indicates the price of organic rice, the price of non-organic rice, the price of chicken egg, education, income, the number of family members, and preference together had an influence on the request of organic rice. The factors that influence individual is organic rice price, non-organic rice price, chicken egg price, and income. The organic rice price elasticity was negative $(-0,683)$ shows that the organic price is inelastic. The income elasticity was positive $(0,611)$ shows that rice organic included in a category of normal good. Non-organic rice price cross elasticity was positive $(1,454)$ means non-organic rice of substitution to organic rice. Chicken egg price cross elasticity was negative $(-1,060)$ means egg of complementary to organic rice.
\end{abstract}

Keywords: Demand, Elasticity, Organic Rice, Regression

\section{PENDAHULUAN}

Seiring berkembangnya jaman, pertanian Indonesia telah berkembang menuju pertanian yang modern. Pertanian modern atau teknologi revolusi hijau sejak tahun 1970-an, mampu meningkatkan produksi dibandingkan tahun 1960-an, namun juga meninggalkan dampak negatif yaitu rusaknya mutu lingkungan dan keanekaragaman hayati (Sumarno, 2006). Pertanian Indonesia terus berkembang ke arah pertanian organik karena munculnya kesadaran tentang bahaya yang ditimbulkan oleh pemakaian bahan kimia sintetis dalam pertanian modern atau teknologi revolusi hijau. Syukur dan Melati (2016) mengatakan bahwa pertanian organik tidak hanya sebatas meniadakan penggunaan input sintetis, tetapi juga pemanfaatan sumber-sumber daya alam secara berkelanjutan, produksi makanan sehat dan menghemat energi. Kebanyakan konsumen akan memilih bahan pangan yang aman bagi kesehatan dan ramah lingkungan.

Pola hidup sehat saat ini sudah menjadi kebutuhan bagi sebagian besar masyarakat di Indonesia (Kusumaningsih et al, 2019). Mereka sadar akan bahan makanan yang sehat yang bersumber dari pertanian organik. Salah satu bahan makanan yang mendasar adalah beras. Kebutuhan beras organik di Indonesia tiap hari semakin meningkat, dapat dilihat dari 
konsumsi beras organik pada tahun 2013-2016 menurut Aliansi Organik Indonesia, 2017 dan 2018.

Konsumsi beras organik dari tahun 2013 sampai 2016 terjadi peningkatan sebesar 14 juta ton. Hal ini karena masyarakat mulai mengerti pentingnya pola hidup sehat dan tumbuhnya kesadaran untuk menjaga mutu lingkungan serta keanekaragaman hayati. Konsumsi yang semakin tinggi setiap tahun mengindikasikan permintaan terhadap beras organik semakin tinggi. Hal ini didukung juga dengan luas panen dan produksi padi tahun 2014 sampai 2017 mengalami peningkatan. Meningkatnya produksi akan beras organik ini mendorong prospek pengembangan beras organik akan terus ke arah positif.

Permintaan konsumen terhadap beras organik dipengaruhi oleh banyak hal, seperti harga beras organik itu sendiri, harga barang substitusi dan komplementer, jumlah penduduk, pendapatan serta selera. terpenuhi (Rahayuningsih et al, 2016). Kota Surakarta sendiri adalah salah satu daerah di Jawa Tengah dengan jumlah penduduk sebesar 514.171 jiwa dan kepadatan penduduk sebesar 11.722 jiwa $/ \mathrm{km}^{2}$ (BPS Surakarta, 2018). Oleh karena itu, penelitian ini bertujuan untuk mengetahui faktor-faktor yang mempengaruhi permintaan beras organik dan mengetahui elastisitas permintaan beras organik dan mendorong penulis untuk melakukan penelitian di Kota Surakarta.

\section{METODE PENELITIAN}

\section{Metode Dasar Penelitian}

Metode dasar yang digunakan dalam penelitian ini adalah metode deskriptif dan analistis. Metode analitis adalah metode yang mendasarkan sebuah penelitian pada hasil analisis ilmiah. Hasil analisis ini kemudian dijelaskan secara deskriptif untuk mendapatkan hasil penelitian sesuai tujuan (Gulo, 2005). Pelaksanaan penelitian dilakukan dengan teknik survei. Umumnya penelitian survei dibatasi pada penelitian yang datanya dikumpulkan dari sampel atas populasi untuk mewakili seluruh populasi.

\section{Metode Pengambilan Lokasi Penelitian}

Penentuan lokasi dilakukan secara purposive (sengaja). Penelitian dilaksanakan di Kota Surakarta, Provinsi Jawa Tengah. Jumlah penduduk di Kota Surakarta menurut data BPS Surakarta (2017) adalah 514.171 jiwa, dengan pertumbuhan penduduk kurun waktu sebelumnya sebesar 1945 jiwa, dengan kepadatan penduduk sebesar $11.722 \mathrm{~km}^{2}$ menurut data BPS Surakarta (2018). Pengambilan sampel dalam penelitian ini dilakukan di seluruh kecamatan di Kota Surakarta.

\section{Metode Penentuan Sampel}

Penentuan sampel pada penelitian ini menggunakan metode accidental sampling. Adapun kriteria sampel yang diambil dalam penelitian ini adalah masyarakat yang pernah atau sedang mengonsumsi beras organik di Kota Surakarta yang secara kebetulan ditemui oleh peneliti di sekitar outlet/pengecer beras dalam wilayah Kota Surakarta, yang bersedia diwawancarai, dengan panduan kuesioner yang telah disediakan dan memenuhi persyaratan untuk penelitian. Sampel yang diambil pada penelitian ini berjumlah 100 responden. 


\section{Jenis dan Sumber Data}

Data Primer yang digunakan dalam penelitian ini meliputi identitas konsumen, yang terdiri dari nama lengkap, umur, jenis kelamin, alamat, pendidikan terakhir, pekerjaan, pendapatan, dan pengeluaran, serta penilaian konsumen terkait dengan pengaruh variabel harga beras organik, harga beras non organik, harga telur ayam, pendapatan konsumen, jumlah anggota keluarga, lama pendidikan dan selera konsumen terhadap permintaan beras organik di Kota Surakarta. Pada penelitian ini data sekunder yang diperoleh dari Badan Pusat Statistik (BPS), selain itu sumber data sekunder adalah dari studi kepustakaan.

\section{Metode Analisis Data}

\section{Analisis Permintaan Beras Organik di Kota Surakarta}

Sebelum melakukan analisis regresi linier berganda, maka data diuji sesuai asumsi klasik yaitu normalitas, multikolinearitas, autokolerasi, dan heterokedastisitas sehingga persamaan yang terbentuk dapat memenuhi kaidah BLUE (Best Linear Unbiased Estimator). Selanjutnya dilakukan uji statistik, uji statistik yang dilakukan antara lain uji koefisien determinasi, uji F, dan uji t (Suliyanto, 2011; Ghozali, 2005; Kennedy, 2003). Model persamaan analisis regresi dalam penelitian ini adalah sebagai berikut:

$$
\mathrm{LnY}=\mathrm{a}+\mathrm{b}_{1} \operatorname{LnX} \mathrm{X}_{1}+\mathrm{b}_{2} \operatorname{Ln} \mathrm{X}_{2}+\mathrm{b}_{3} \operatorname{Ln} \mathrm{X}_{3}+\mathrm{b}_{4} \operatorname{Ln} \mathrm{X}_{4}+\mathrm{b}_{5} \operatorname{LnX} \mathrm{X}_{5}+\mathrm{b}_{6} \operatorname{LnX}_{6}+\mathrm{b}_{7} \mathrm{D}_{1}+\mathrm{e} .
$$

dimana :

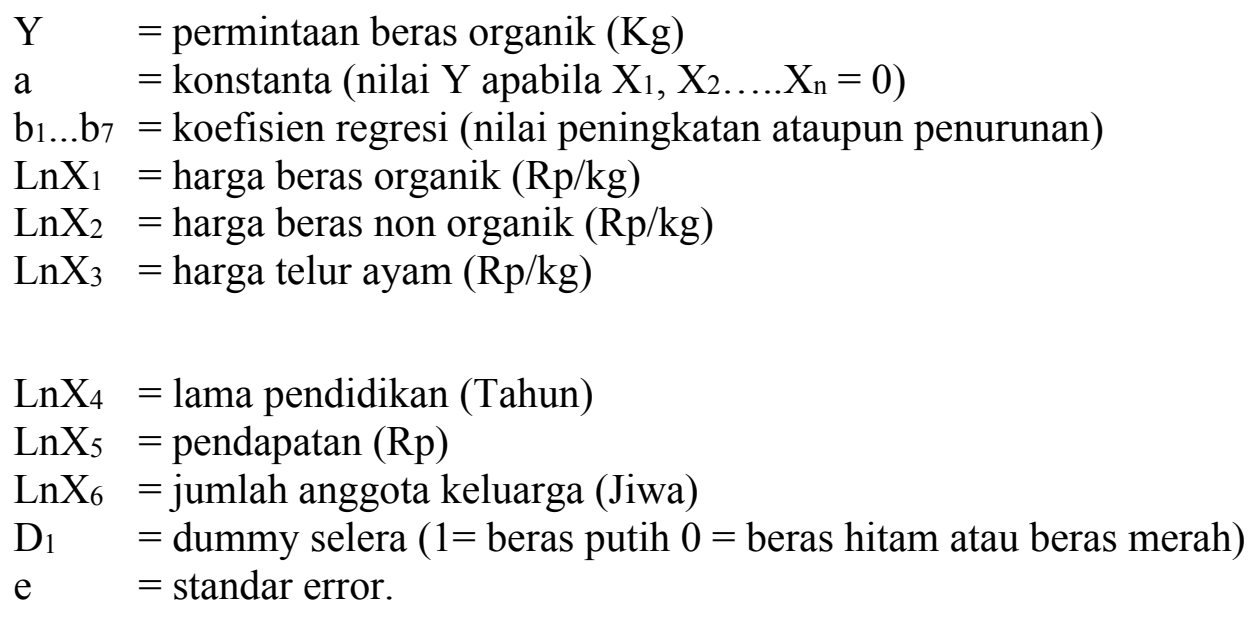

Fungsi tersebut ditransformasikan dalam bentuk linear dengan menggunakan logaritma natural (Ln) guna menghitung nilai elastisitas dari masing-masing variabel bebas terhadap variabel terikat ke dalam model regresi.

\section{Analisis Elastisitas}

Elastisitas dari fungsi permintaan dapat diketahui dengan melihat dari nilai koefisien regresi dari masing-masing variabel bebas Elastisitas permintaan terdiri dari elastisitas harga, elastisitas pendapatan, dan elastisitas silang. Elastisitas harga adalah tingkat kepekaan relatif dari jumlah beras organik yang diminta oleh konsumen, akibat adanya perubahan harga beras organik, nilai elastisitas harga dapat ditunjukkan oleh nilai koefisien regresi variabel harga beras organik. Elastisitas pendapatan adalah tingkat kepekaan relatif yang menunjukkan besarnya perubahan permintaan terhadap beras organik akibat perubahan pendapatan, nilai elastisitas pendapatan dapat ditunjukkan oleh nilai koefisien regresi variabel pendapatan. 
Elastisitas silang adalah tingkat kepekaan relatif yang menunjukkan besarnya perubahan permintaan beras organik akibat adanya perubahan terhadap harga barang lain, nilai elastisitas silang dapat ditunjukkan oleh nilai koefisien regresi variabel beras non organik dan harga telur ayam.

\section{HASIL DAN PEMBAHASAN}

\section{Hasil Analisis}

\section{Karakteristik Responden}

Karakteristik responden yang digunakan untuk mengetahui keragaman dari responden berdasarkan umur, pendidikan, lokasi pembelian dan jenis beras organik di Kota Surakarta.

a. Karakteristik Responden Berdasarkan Umur

Umur merupakan salah satu hal yang dapat mempengaruhi cara berpikir seseorang sehingga akan berpengaruh pula pada perilaku konsumen seperti perbedaan selera konsumsi pada suatu produk. Perbedaan umur akan mengakibatkan perbedaan kebutuhan terhadap suatu produk yang memiliki berbagai macam variasi. Pada umumnya, Karakteristik responden yang mengonsumsi beras organik di Kota Surakarta berdasarkan umur dapat dilihat pada Tabel 1.

Kelompok umur dibagi untuk setiap jangka usia lima tahunan, hal ini disesuaikan dengan pembagian kelompok umur yang dilakukan oleh Badan Pusat Statistik Indonesia. Tabel 1 menggambarkan bahwa di Kota Surakarta, usia konsumen beras organik berada di atas usia 20. Responden yang mengonsumsi beras organik paling banyak berada pada kelompok umur 25-29, yang memiliki jumlah sebesar 17 orang.

Tabel 1. Karakteristik Responden yang Mengonsumsi Beras Organik di Kota Surakarta Berdasarkan Umur

\begin{tabular}{|c|c|c|c|}
\hline No. & Umur (Tahun) & $\begin{array}{c}\text { Jumlah Responden } \\
\text { (Orang) }\end{array}$ & Persentase (\%) \\
\hline 1. & $20-24$ & 2 & 2 \\
\hline 2. & $25-29$ & 17 & 17 \\
\hline 3. & $30-34$ & 8 & 8 \\
\hline 4. & $35-39$ & 13 & 13 \\
\hline 5. & $40-44$ & 15 & 15 \\
\hline 6. & $45-49$ & 12 & 12 \\
\hline 7. & $50-54$ & 14 & 14 \\
\hline 8. & $55-59$ & 9 & 9 \\
\hline 9. & $60-64$ & 7 & 7 \\
\hline 10. & $>65$ & 3 & 3 \\
\hline & Jumlah & 100 & 100 \\
\hline
\end{tabular}

Sumber : Analisis Data Primer, 2019

b. Karakteristik Responden Berdasarkan Pendidikan 
Pendidikan merupakan salah satu faktor bagi konsumen beras organik untuk memahami pentingnya mengonsumsi beras organik. Pendidikan yang baik dapat mengubah pola pikir responden untuk memenuhi gizinya dengan asupan sehat seperti mengonsumsi beras organik. Selain itu, pendidikan yang baik dapat mempengaruhi keputusan pembelian rumah tangga untuk membeli beras organik ini sebagai makanan yang dikonsumsi keluarganya. Karakteristik responden yang mengonsumsi beras organik di Kota Surakarta berdasarkan pendidikan dapat dilihat pada Tabel 2.

Tabel 2. Karakteristik Responden yang Mengonsumsi Beras Organik di Kota Surakarta Berdasarkan Pendidikan

\begin{tabular}{clcc}
\hline No. & Tingkat Pendidikan & $\begin{array}{c}\text { Jumlah Responden } \\
\text { (Orang) }\end{array}$ & Persentase (\%) \\
\hline 1. & Tidak tamat SD & 0 & 0 \\
2. & SD & 0 & 0 \\
3. & SMP & 1 & 1 \\
4. & SMA & 21 & 21 \\
5. & Perguruan Tinggi & 78 & 78 \\
& Jumlah & $\mathbf{1 0 0}$ & $\mathbf{1 0 0}$ \\
\hline
\end{tabular}

Sumber: Analisis Data Primer, 2019

Berdasarkan Tabel 2, tingkat pendidikan responden yang mengonsumsi beras organik di Kota Surakarta berada pada jenjang SMP hingga perguruan tinggi. Sebagian besar responden merupakan lulusan perguruan tinggi dengan jumlah 78 orang. Responden pada tingkat pendidikan SMA adalah sebanyak 21 orang dan tingkat pendidikan terendah adalah SMP sebanyak 1 orang

c. Karakteristik responden berdasarkan selera

Selera didefinisikan sebagai kesukaan konsumen beras organik terhadap jenis beras organik yaitu beras putih, beras merah, atau beras hitam. Selera merupakan salah satu faktor yang mempengaruhi permintaan beras organik. Karakteristik responden berdasarkan selera, dapat dilihat pada Tabel 3.

Tabel 3. Karakteristik Responden yang Mengonsumsi Beras Organik di Kota Surakarta Berdasarkan Selera

\begin{tabular}{clcc}
\hline No. & Jenis Beras Organik & $\begin{array}{c}\text { Jumlah Responden } \\
\text { (Orang) }\end{array}$ & Persentase (\%) \\
\hline 1. & Beras Putih & 53 & 53 \\
2. & Beras Merah & 44 & 44 \\
3. & Beras Hitam & 3 & 3 \\
& Jumlah & $\mathbf{1 0 0}$ & $\mathbf{1 0 0}$ \\
\hline
\end{tabular}

Sumber: Data Primer, 2019 
Berdasarkan Tabel 3 dapat dilihat bahwa sebanyak 53 responden menyukai beras putih. Beras merah disukai oleh 44 responden. Jenis beras yang paling jarang dikonsumsi responden adalah beras hitam, hanya 3 responden yang menyukai beras tersebut.

d. Karakteristik berdasarkan tempat pembelian

Tempat pembelian merupakan lokasi di mana responden membeli beras organik di wilayah Kota Surakarta. Karakteristik responden berdasarkan tempat pembelian dapat dilihat pada Tabel 4.

Tabel 4. Karakteristik Responden yang Mengonsumsi Beras Organik di Kota Surakarta Berdasarkan Tempat Pembelian

\begin{tabular}{clcc}
\hline No. & Tempat Pembelian & $\begin{array}{c}\text { Jumlah Responden } \\
\text { (Orang) }\end{array}$ & Persentase (\%) \\
\hline 1. & Pasar Tradisional & 66 & 66 \\
2. & Online & 6 & 6 \\
3. & Pasar dan Swalayan & 18 & 18 \\
4. & Pasar dan online & 10 & 10 \\
& Jumlah & $\mathbf{1 0 0}$ & $\mathbf{1 0 0}$ \\
\hline
\end{tabular}

Sumber: Analisis Data Primer, 2019

Berdasarkan Tabel 4, tempat pembelian yang paling banyak didatangi responden untuk membeli beras organik adalah pasar tradisional, sebanyak 66 orang. Selanjutnya pasar dan swalayan sebanyak 18 orang. Tempat pembelian yang kurang diminati adalah secara online.

\section{Permintaan Beras Organik}

Permintaan beras organik didefinisikan sebagai jumlah konsumsi beras organik untuk rumah tangga dalam satu bulan yang dinyatakan dalam satuan kilogram. Sampel pada penelitian ini berjumlah 100 sampel data. Nilai mean menunjukkan rata-rata dari data yang ada, standar deviasi adalah suatu indeks yang menggambarkan sebaran data terhadap rataratanya. Nilai minimum adalah nilai terendah yang ada pada suatu data dalam total sampel data, sedangkan nilai maksimum adalah nilai tertinggi yang ada pada suatu data yang terdapat di dalam sampel data. Berdasarkan hasil analisis rata-rata (mean) permintaan beras organik dari semua responden adalah 6,2 kg/bulan dengan simpangan baku (standar deviasi) 3,87 $\mathrm{kg} /$ bulan. Permintaan beras organik terendah adalah $1,0 \mathrm{~kg} /$ bulan sedangkan permintaan tertinggi adalah $15,0 \mathrm{~kg} / \mathrm{bulan}$.

\section{Pembahasan}

Berdasarkan hasil analisis data dengan SPSS metode regresi maka diperoleh hasil-hasil analisis untuk merumuskan permintaan beras organik di Kota Surakarta. Model regresi linier ganda yang disusun terdiri atas permintaan beras organik sebagai variabel dependen dan 7 variabel independen yaitu harga beras organik, harga beras non organik, harga telur ayam, lama pendidikan, pendapatan, jumlah anggota keluarga, dan selera.

Berdasarkan hasil analisis yang diperoleh, fungsi permintaan beras organik di Kota Surakarta adalah

$\operatorname{LnY}=-4,297-0,683 \operatorname{LnX}_{1}+1,454 \operatorname{LnX}_{2}-1,060 \operatorname{LnX}_{3}+0,053 \operatorname{LnX}_{4}+0,611 \operatorname{LnX}_{5}+0,256$

LnX $6-0,097 \mathrm{D}$ 
Apabila seluruh variabel bebas berupa harga beras organik $\left(\mathrm{X}_{1}\right)$, harga beras non organik $\left(\mathrm{X}_{2}\right)$, harga telur ayam $\left(\mathrm{X}_{3}\right)$, lama pendidikan $\left(\mathrm{X}_{4}\right)$, pendapatan $\left(\mathrm{X}_{5}\right)$, jumlah tanggungan keluarga $\left(\mathrm{X}_{6}\right)$, dan selera $\left(\mathrm{D}_{1}\right)$ sebesar nol, maka $\mathrm{Y}$ atau permintaan sebesar $-4,297 \mathrm{~kg}$.

Tabel 5. Hasil Analisis Permintaan Beras Organik di Kota Surakarta

\begin{tabular}{|c|c|c|c|c|}
\hline Variabel & $\begin{array}{c}\text { Koefisien } \\
\text { Regresi }\end{array}$ & $\begin{array}{r}\text { Std. } \\
\text { Error }\end{array}$ & $\mathbf{t}$ & Sig. \\
\hline (Constant) & $-4,297$ & 6,962 & 0,697 & 0,032 \\
\hline Harga beras organik $\left(\mathrm{X}_{1}\right)$ & $-0,683 * *$ & 0,275 & $-2,483$ & 0,015 \\
\hline Harga beras non organik $\left(\mathrm{X}_{2}\right)$ & $1,454 * * *$ & 0,432 & 3,368 & 0,001 \\
\hline Harga telur ayam $\left(\mathrm{X}_{3}\right)$ & $-1,060 * *$ & 0,462 & $-2,295$ & 0,024 \\
\hline Lama Pendidikan $\left(\mathrm{X}_{4}\right)$ & 0,053 & 0,419 & 0,126 & 0,900 \\
\hline Jumlah pendapatan $\left(\mathrm{X}_{5}\right)$ & $0,611 * * *$ & 0,155 & 3,936 & 0,000 \\
\hline Jumlah anggota keluarga $\left(\mathrm{X}_{6}\right)$ & 0,256 & 0,183 & 1,394 & 0,167 \\
\hline Selera $\left(D_{1}\right)$ & $-0,097$ & 0,110 & 0,881 & 0,381 \\
\hline $\mathrm{R}^{2}$ & 0.591 & & & \\
\hline F Hitung & $18,957 * * *$ & & & 0,000 \\
\hline Jumlah data & 100 & & & \\
\hline
\end{tabular}

Sumber : Analisis Data Primer, 2019

Pengujian perlu dilakukan agar hasil yang ingin didapatkan tepat dan relevan. Untuk memperoleh hasil regresi yang terbaik maka harus memenuhi kriteria statistik yang dapat diukur dari nilai koefisien determinasi, nilai statistik F, dan nilai statistik t.

Koefisien determinasi yang disimbolkan dengan $\mathrm{R}^{2}$ merupakan suatu nilai yang menyatakan besarnya variasi nilai variabel dependen yang dapat dijelaskan dengan model regresi. Model regresi yang disusun dalam penelitian ini memiliki nilai $\mathrm{R}^{2}$ sebesar 0,591 atau $59,1 \%$. Artinya, harga beras organik, harga beras non organik, harga telur ayam, lama pendidikan, pendapatan, jumlah anggota keluarga, dan selera, memiliki kontribusi pengaruh sebesar $59,1 \%$ terhadap permintaan beras organik. Dengan demikian masih terdapat $(100 \%-$ $59,1 \%)=40,9 \%$ variabel di luar model yang tidak diteliti.

Analisis uji F menunjukkan signifikansi (Sig.) sebesar 0,000. Nilai signifikansi $<0,01$ berarti bahwa model regresi merupakan prediktor signifikan atau dengan kata lain semua variabel independen (harga beras organik, harga beras non organik, harga telur ayam, lama pendidikan, pendapatan, jumlah anggota keluarga, dan selera secara simultan (bersama-sama) berpengaruh signifikan terhadap permintaan beras organik pada tingkat kepercayaan $99 \%$.

Signifikansi dari model regresi diketahui lewat uji t yang digunakan untuk mengetahui apakah suatu variabel bebas berpengaruh secara parsial (individu) terhadap permintaan beras organik di Kota Surakarta disajikan pada Tabel 5.

Harga beras organik yang dinotasikan $\left(\mathrm{X}_{1}\right)$ dalam model regresi memiliki koefisien bernilai negatif $(-0,683)$ yang artinya setiap terjadi kenaikan harga beras organik sebesar $1 \%$ akan menurunkan permintaan beras organik sebesar $0,683 \%$. Uji statistiknya menghasilkan signifikansi (Sig.) sebesar 0,015. Oleh karena signifikansi < 0,01 maka harga beras organik 
berpengaruh nyata secara individu atau parsial terhadap permintaan beras organik. Semakin tinggi harga beras organik maka semakin rendah permintaan beras organik begitupun sebaliknya. Ini sesuai dengan teori hukum permintaan yang menyatakan bahwa jika harga suatu barang naik, maka jumlah barang yang diminta akan menurun. Sebaliknya jika harga suatu barang turun maka jumlah barang yang diminta akan meningkat (Sumarsono, 2007).

Harga beras non organik yang dinotasikan $\left(\mathrm{X}_{2}\right)$ dalam model regresi memiliki koefisien bernilai positif $(1,454)$ yang artinya setiap terjadi kenaikan harga beras non organik sebesar $1 \%$ akan menaikkan permintaan beras organik sebesar $1,454 \%$. Uji statistiknya menghasilkan signifikansi (Sig.) sebesar 0,001. Oleh karena signifikansi $<0,01$ maka harga beras nonorganik berpengaruh nyata secara individu atau parsial terhadap permintaan beras organik. Semakin tinggi harga beras non organik maka semakin tinggi permintaan beras organik. Temuan ini tidak senada dengan hasil penelitian Rahayuningsih et al (2016) yang menyimpulkan bahwa harga beras non organik tidak berpengaruh signifikan terhadap permintaan beras organik. Perbedaan hasil penelitian ini dapat disebabkan karena perbedaan karakteristik kedua obyek penelitian. Masyarakat Surakarta secara umum memiliki karakteristik masyarakat perkotaan dengan tingkat pendidikan, ekonomi, dan sosial yang lebih tinggi dibandingkan masyarakat Boyolali yang sebagian besar memiliki karakteristik masyarakat pedesaan.

Harga telur ayam yang dinotasikan $\left(\mathrm{X}_{3}\right)$ dalam model regresi memiliki koefisien bernilai negatif $(-1,060)$ yang artinya setiap terjadi kenaikan harga telur ayam sebesar $1 \%$ akan menurunkan permintaan beras organik sebesar $1,060 \%$. Uji statistiknya signifikansi (Sig.) sebesar 0,024 . Oleh karena signifikansi $<0,05$ maka harga telur ayam berpengaruh nyata secara individu atau parsial terhadap permintaan beras organik. Semakin tinggi harga telur ayam maka semakin rendah permintaan beras organik. Temuan ini didukung dengan hasil penelitian Mulyo (2011) yang menyimpulkan bahwa harga telur merupakan salah satu faktor yang berpengaruh terhadap permintaan beras.

Lama pendidikan yang dinotasikan $\left(\mathrm{X}_{4}\right)$ dinyatakan secara individu atau parsial tidak berpengaruh signifikan terhadap permintaan beras organik. Hasil ini senada dengan hasil penelitian Risty et al (2012) di Kota Medan yang menyimpulkan bahwa lama pendidikan tidak berpengaruh secara signifikan terhadap permintaan beras organik. Lama pendidikan yang tidak berpengaruh signifikan ini dapat disebabkan karena setiap individu dapat memperoleh informasi tentang manfaat beras organik dari berbagai macam sumber informasi, seperti internet, kerabat, saudara, dan tetangga baik pada individu dengan pendidikan rendah maupun individu dengan tingkat pendidikan yang tinggi.

Pendapatan yang dinotasikan $\left(\mathrm{X}_{5}\right)$ dalam model regresi memiliki koefisien bernilai positif $(0,611)$ yang artinya setiap terjadi kenaikan pendapatan sebesar $1 \%$ akan menaikkan permintaan beras organik sebesar $0,611 \%$. Uji statistik menunjukkan signifikansi (Sig.) sebesar 0,000 . Oleh karena signifikansi $<0,01$ maka pendapatan berpengaruh nyata secara individu atau parsial terhadap permintaan beras organik. Semakin tinggi pendapatan maka semakin tinggi permintaan beras organik. Hasil ini didukung oleh hasil penelitian Risty (2012) yang menyimpulkan bahwa pendapatan berpengaruh secara signifikan terhadap permintaan beras organik. Pengaruh signifikan pendapatan terhadap permintaan beras secara umum juga telah dibuktikan sebelumnya dalam penelitian yang dilakukan oleh Laily (2016), Mulyo (2011), dan Sunaryati (2016). 
Jumlah anggota keluarga yang dinotasikan $\left(\mathrm{X}_{6}\right)$ dinyatakan secara individu atau parsial tidak berpengaruh signifikan terhadap permintaan beras organik. Hasil ini senada dengan penelitian Silitonga dan Salman (2014). Jumlah anggota keluarga tidak berpengaruh signifikan dapat disebabkan tidak semua anggota keluarga yang mengonsumsi beras organik, hanya anggota keluarga tertentu yang membutuhkan manfaat khusus dari beras organik.

Selera terkait dengan jenis beras organik dinyatakan secara parsial tidak berpengaruh signifikan terhadap permintaan beras organik. Selera dalam penelitian ini dikategorikan menjadi dua preferensi konsumen yaitu beras putih dan beras hitam atau merah. Hasil ini didukung dengan hasil penelitian Laily (2016) yang menyimpulkan bahwa selera konsumen tidak berpengaruh secara signifikan terhadap permintaan beras. Hal ini dapat karena tidak jauh berbeda rasa maupun tekstur dari berbagai jenis beras organik yang di jual di Kota Surakarta.

\section{Analisis Elastisitas}

Elastisitas permintaan dapat diartikan sampai di mana responsifnya perubahan permintaan sebagai akibat dari perubahan faktor-faktor penentu permintaan. Nilai elastisitas dinyatakan oleh koefisien regresi variabel-variabel independen.

Elastisitas harga beras organik adalah persentase perubahan jumlah permintaan beras organik yang disebabkan oleh perubahan dari harga beras organik tersebut. Nilai elastisitas harga dinyatakan dengan koefisien regresi harga beras organik yaitu sebesar $-0,683$ sesuai dengan Tabel 5. Nilai elastisitas $\left(\varepsilon_{\mathrm{h}}<1\right)$ menunjukkan bahwa harga terhadap permintaan termasuk dalam kategori in elastis. Artinya, setiap perubahan harga beras organik $1 \%$ mengakibatkan perubahan permintaan beras organik kurang dari $1 \%$ yaitu sebesar $0,683 \%$. Hasil penelitian ini sesuai dengan hasil penelitian Sulistyana et al (2014) yang menyatakan bahwa beras organik merupakan barang yang in elastis dengan nilai koefisien regresi pada variabel harga beras organik sebesar $-0,014$.

Elastisitas pendapatan adalah persentase perubahan jumlah permintaan beras organik yang disebabkan oleh perubahan pendapatan. Nilai elastisitas pendapatan dinyatakan dengan koefisien regresi pendapatan yaitu sebesar 0,611 sesuai dengan Tabel 5. Nilai elastisitas sebesar 0,611 $\left(\varepsilon_{\mathrm{p}}>0\right)$ menunjukkan bahwa beras organik termasuk dalam kategori barang normal. Nilai elastisitas pendapatan sebesar 0,611 juga berarti bahwa ketika perubahan pendapatan konsumen naik 1\%, maka permintaan beras organik akan mengalami perubahan sebesar 0,611\%. Hasil ini senada dengan penelitian Rahayuningsih, et al (2016) yang menyatakan bahwa beras organik adalah barang normal.

Nilai elastisitas silang dinyatakan dengan koefisien regresi harga beras non organik dan harga telur ayam. Harga beras non organik memiliki koefisien regresi sebesar 1,454 sesuai dengan Tabel 5. Nilai elastisitas sebesar 1,454 $\left(\varepsilon_{\mathrm{xy}}>0\right)$ berarti bahwa setiap perubahan harga beras non organik sebesar $1 \%$, akan mengakibatkan perubahan permintaan beras organik sebesar $1,454 \%$. Hal ini menunjukkan bahwa beras non organik merupakan barang substitusi untuk beras organik. Temuan ini didukung dengan hasil penelitian Sulistyana (2014) yang menyimpulkan bahwa beras non organik merupakan salah satu barang substitusi terhadap beras organik. 
Harga telur ayam memiliki koefisien regresi sebesar $-1,060$ sesuai dengan Tabel 5. Nilai elastisitas sebesar $-1,060\left(\mathcal{E}_{\mathrm{xy}}<0\right)$ berarti setiap kenaikan harga telur ayam sebesar $1 \%$, akan mengakibatkan kenaikan permintaan beras organik sebesar 1,060\%. Hal ini menunjukkan bahwa telur ayam merupakan barang komplementer untuk beras organik. Temuan sesuai dengan hasil penelitian Mulyo (2011) yang menyimpulkan bahwa harga telur merupakan salah satu faktor yang berpengaruh terhadap permintaan beras.

\section{KESIMPULAN DAN SARAN}

\section{Kesimpulan}

Harga beras organik, harga beras non organik, harga telur ayam, lama pendidikan, pendapatan, jumlah anggota keluarga, dan selera secara bersama-sama berpengaruh terhadap permintaan beras organik. Adapun faktor yang berpengaruh secara individu atau parsial adalah harga beras organik, harga beras non organik, harga telur ayam, dan pendapatan. Permintaan beras organik bersifat in elastis. Terkait dengan elastisitas pendapatan, beras organik termasuk barang normal. Terkait dengan elastisitas silang, beras nonorganik merupakan barang substitusi sedangkan telur ayam merupakan barang komplementer.

\section{Saran}

Harga beras organik di pasaran relatif tinggi dan cenderung fluktuatif sehingga perlu adanya pengaturan Harga Eceran Tertinggi untuk beras organik agar terjangkau oleh konsumen. Tempat pembelian beras organik di pasar tradisional sangat minim, ini memunculkan peluang usaha, untuk membuka outlet penjualan beras organik sehingga memudahkan konsumen untuk mencari beras organik di seluruh wilayah Kota Surakarta.

\section{DAFTAR PUSTAKA}

Aliansi Organik Indonesia. (2017). Statistik Pertanian Organik Indonesia 2016. Bogor.

Aliansi Organik Indonesia. (2018). Statistik Pertanian Organik Indonesia 2017. Bogor.

Arsyad, L. (2008). Ekonomi Manajerial. Yogyakata: BPFE.

BPS. (2017). Kota Surakarta dalam Angka 2017. Badan Pusat Statistik, Kota Surakarta, Surakarta.

BPS. (2018). Hasil Survey Volume Penjualan Beras Eceran di Kota Surakarta Tahun 2018. Badan Pusat Statistik, Kota Surakarta, Jawa Tengah.

BPS. (2018). Kota Surakarta dalam Angka 2018. Kota Surakarta, Badan Pusat Statistik, Surakarta .

BPS. (2018). Ringkasan Eklusif Luas Panen dan Produksi Beras 2018. Badan Pusat Statistik, Jakarta, Indonesia.

Suliyanto. (2011). Ekonometrika Terapan: Teori dan Aplikasi dengan SPSS. Yogyakarta: Andi Yogyakarta.

Ghozali, I. (2005). Aplikasi Analisis Multivariate dengan SPSS. Semarang: Badan Penerbit Universitas Diponegoro.

Gulo, W. (2005). Metodologi Penelitian. Jakarta: Grasindo. 
Kennedy, P. (2003). A Guide to Econometrics. United Kingdom: MPG Book, Bodmin, Cornwall.

Laily, Z. (2016). Analisis Faktor-faktor yang mempengaruhi permintaan beras di Kabupaten Kudus Provinsi Jawa Tengah. Prosiding Seminar Nasional Hasil-Hasil Penelitian Pascasarjana. Semarang: SPS UNDIP.

Mulyo, H. (2011). Analisis Permintaan Beras di Kabupaten Klaten. Surakarta, Universitas Sebelas Maret.

Rahayuningsih, P., Prasetyowati, K., S.Suswadi, \& M. Mahananto. (2016). Analisis Permintaan Beras Organik di Kabupaten Boyolali. Agrineca, 16 No. 2:51.

Risty, C., Ikandarin, Rahmanta, \& Ginting. (2012). Elastisitas Permintaan Beras Organik di Kota Medan. Jurnal Pertanian Universitas Sumatra Utara.

Silitonga, Juprianto , \& Salman. (2014, April). Analisis Permintaan Konsumen terhadap Sayuran Organik di Pasar Modern Kota Pekanbaru. Jurnal Dinamika Pertanian, XXIX Nomor 1, 79 86.

Sulistyana, Pradesi, Handoyo , J., \& Jamhari. (2014). Konsumsi Beras Organik pada Tingkat Rumah Tangga di Kota Yogyakarta. Jurnal Agro Ekonomi, 24.

Sumarno. (2006). Sistem Produksi Padi Berkelanjutan dengan Penerapan Revolusi Hijau Lestari. IPTEK Tanaman Pangan, 1, No. 1.

Sumarsono, S. (2007). Ekonomi Mikro. Yogyakarta: Graha Ilmu.

Sunaryati, R. (2016, Desember). Analisis Permintaan Beras di Provinsi Kalimantan Tengah. Jurnal Daun, 3 No. 2, 99-107.

Syukur, M., \& Melati, M. (2016). Perkembangan Pertanian Organik di Indonesia. Bogor: IPB Press. 